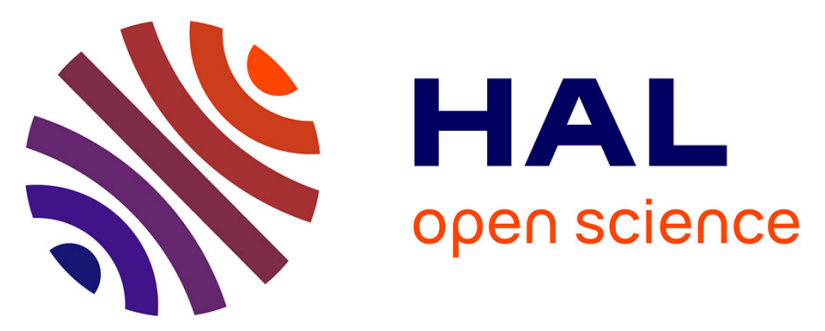

\title{
Variability of eight Algerian oleaster ecotypes (Olea europaea subsp. europaea var. sylvestris [Mill.] Lehr): pollen and exine morphology in relation to geo-climatic effect
}

Khedidja Khouatmiani, Safia Belhadj, Alain Tonetto, Axel Assie, J.P. Mevy, Thierry Gauquelin

\section{To cite this version:}

Khedidja Khouatmiani, Safia Belhadj, Alain Tonetto, Axel Assie, J.P. Mevy, et al.. Variability of eight Algerian oleaster ecotypes (Olea europaea subsp. europaea var. sylvestris [Mill.] Lehr): pollen and exine morphology in relation to geo-climatic effect. Grana, 2021, 60 (4), pp.256-270. 10.1080/00173134.2020.1815832 . hal-02976089

\section{HAL Id: hal-02976089 \\ https://hal-amu.archives-ouvertes.fr/hal-02976089}

Submitted on 20 Apr 2021

HAL is a multi-disciplinary open access archive for the deposit and dissemination of scientific research documents, whether they are published or not. The documents may come from teaching and research institutions in France or abroad, or from public or private research centers.
L'archive ouverte pluridisciplinaire HAL, est destinée au dépôt et à la diffusion de documents scientifiques de niveau recherche, publiés ou non, émanant des établissements d'enseignement et de recherche français ou étrangers, des laboratoires publics ou privés.

\section{(1) (1) $\$$}

Distributed under a Creative Commons Attribution - NonCommercial - NoDerivatives $\mid 4.0$ 


\title{
Variability of eight Algerian oleaster ecotypes (Olea europaea subsp. europaea var. sylvestris [Mill.] Lehr): pollen and exine morphology in relation to geo-climatic effect
}

\author{
KHEDIDJA KHOUATMIANI ${ }^{1,2}$, SAFIA BELHADJ ${ }^{3}$, ALAIN TONETTO $\quad$, \\ AXEL ASSIE ${ }^{4}$, JEAN PHILIPPE MEVY $\quad{ }^{5} \&$ THIERRY GAUQUELIN $\quad 5$
}

\begin{abstract}
${ }^{1}$ Faculté des Sciences de la Nature et de la Vie, Université Hassiba Benbouali, Chleff, Algeria, ${ }^{2}$ Faculté des Sciences de la Nature et de la Vie E্ des Sciences de la Terre, Université Djilali Bounaama, Khemis Miliana, Algeria, ${ }^{3}$ Faculté des Sciences de la Nature et de la Vie, Ziane Achour University, Djelfa, Algeria, ${ }^{4}$ Aix Marseille Univ, CNRS, Centrale Marseille, FSCM, PRATIM, Marseille, France, ${ }^{5}$ Aix Marseille Université, Avignon Université, CNRS, IRD, IMBE, Marseille, France
\end{abstract}

Abstract

Pollen characters of the Algerian oleaster (Olea europaea subsp. europaea var. sylvestris [Mill.] Lehr) from eight ecotypes were analysed to evaluate the geo-climatic effect of their environment. Samples were collected along an altitudinal gradient from western to central Algeria. Eighteen morphological characters of the pollen grains were studied using scanning electron microscopy (SEM). The results show significant inter-populations variability. The geo-climatic conditions, duration and timing of dry periods vary from one area to another. Depending on the area, the length of the dry period $\left(P_{\mathrm{p}} \leq 2 T\right)$ coincides more or less with anthesis periods. No significant geo-climatic effects on exine parameters were detected, except for lumina density (LD) and mean lumina diameter (Lm). However, polar axis $(P)$, pollen size index (PSI) and pollen colpis length (PCL) were found to be related to latitude, longitude and temperature. LD and Lm were strongly linked to the pollen parameters, resulting in variation in pollen shape and size. Depending on the geo-climatic conditions, three morphotypes appear. The morphotype from a site with high temperature, low humidity associated with a long dry period is characterised by small pollen size, low lumina surface area and high lumina density/100 $\mu \mathrm{m}^{2}$ and vice versa. The results indicate that the exine has played an important role in the environmental adaption in these wild populations.

Keywords: wild olive, crop wild relatives, SEM, image analysis, multivariate analysis, geoclimatic adaptation

The Mediterranean olive tree or oleaster (Olea europaea subsp. europaea var. sylvestris [Mill.] Lehr) is distributed all around the Mediterranean Sea (Breton et al. 2012; Kaniewski et al. 2012). The different Oleaster forms are considered by several researchers as the wild precursors of the cultivated olive tree because of their morphological and genetic affinities (Breton et al. 2012).

Olea europaea L. is classified as a complex group, either as a subspecies (subspecies oleaster [Hoffm. et Link] Hegi) or as a variety (var. sylvestris [Mill.] Lehr $=$ var. oleaster $[$ Hoffm. et Link] DC) (Zohary \& Hopf 2000). Some authors consider oleaster populations as forms that have returned to the wild (feral form). However, there is so-called (true) oleaster that seems to be wild natural forms. The morphological distinction between the two forms is not clear (Besnard \& Bervillé 2000). The confusion between the two forms of the wild olive tree (feral and true) as well as between the cultivars of the cultivated olive tree may be due to the fact that, the two wild forms as well as the cultivated olive tree are interfertile (Langgut et al. 2019).

Several studies has been carried out on pollen from Olea europaea var. sativa ([Weston] Lehr) to unravel 
its evolution (Liphschitz et al. 1991) as well as pollen development, morphology and exine structure as morphological markers for distinguishing different cultivars (Pacini \& Juniper 1979a, 1979b; Fernández \& Rodríguez-García 1989; Bartolini et al. 1992; Lanza et al. 1996; Najmaddin 2016; Messora et al. 2017; Laaribi et al. 2018), its viability and germination (Alba et al. 2011; Silva et al. 2016), and its conservation and various forms of sterility (Ateyyeh 2009). However, it was Roselli (1979) who pioneered the use of the pollen exine ultra-structure in his investigations for olive cultivars characterisations and identification (Ganino et al. 2006).

The real challenge for olive-growing countries is to achieve self-sufficiency and to develop better quality products. Some countries have breeding programmes, which initially focused on conventional cultivars and later found it necessary to draw on wild crop relatives as the wild crop relatives are more diverse genetically than cultivated types. Indeed, agro-morphological, biochemical and molecular studies have confirmed the high diversity of the wild species; these interesting characteristics hold agronomic and biotechnological potential and may allow cultivated species to acquire back some useful genetic material (Hannachi \& Marzouk 2012; Klepo et al. 2013, 2014). Other countries have addressed the production challenge by increasing the area planted (extensive farming). For instance, Algeria set under the national plan for agriculture and rural development a target of one million hectares of olive trees for 2010-2014 (Bouarissa 2010).

The oleaster brings to the-cross-bred trees (oleaster $\times$ cultivars) good vigour, short juvenile period and good oil quality (Hannachi \& Marzouk 2012; Klepo et al. 2013).

In North Africa, the oleaster most often grows in association with the mastic pistachio tree (Pistacia lentiscus), the Oleo-Lentiscetum group whose natural habitat covers the plains and low hills (up to $700 \mathrm{~m}$ in altitude), from the North African shores to the High Plains. Nevertheless, its current area is continuously shrinking due to land clearing for the expansion of olive growing (Harfouche et al. 2005).

The study of wild olive tree populations of different origins as a source of new genetic variation is one of the important objectives of olive breeding programmes (Abood et al. 2017). However, little has been done to assess the genetic resources of the oleaster in Algeria, despite being one of the most important forest and fruit crops in terms of socio-economic, environmental and agronomic impacts. To the best of our knowledge, no morpho-metric study of the Olea europaea subsp. europaea var. sylvestris) pollen has been carried out in Algeria, so far.
This study assesses inter-populations (intra-specific) variability among eight oleaster populations, collected according to an altitudinal gradient, from eight different sites in Algeria, and assesses the effect of the geoclimatic environment on this variability. The variability covers the micro-morphological parameters of pollen grains and exine structure, using 18 descriptors in total (seven pollen parameters as well as 11 exine features) through a combination of three tools, namely scanning electron microscopy (SEM), imaging and multivariate analysis.

\section{Material and methods}

\section{Study sites and plant material}

Flowers at the white-bud stage of Olea europaea subsp. europaea var. sylvestris) were collected from eight sites distributed over five regions from western to central Algeria. One site is sampled in each of the following localities: Ghelizane (GH), Chlef (Chl), Blida (B) and Tipaza (T), while four sites were sampled in the locality of Ain-Defla (ADL1, ADL2, ADL3 and ADL4) (Figure 1).

From each site flowers were collected randomly from three trees, making a total of 24 samples. The sampling was carried out according to an altitudinal gradient (Table I) with additional information on population, origin of samples and climatic characteristics of the sites. Climatic data were gathered over 35 years. Monthly temperature and precipitation data were plotted on the ombro-thermal diagrams of Bagnouls and Gaussen (1957) and used for establishing the $P_{\mathrm{p}} / T$ ratio (with, $P_{\mathrm{p}}$ for precipitation and $T$ for temperature), the evaluation of the monthly aridohumidity index is calculated according to Rivas-Martinez (2005) method.

\section{SEM observation of pollen grains}

SEM observations of pollen grains followed the method of Bartolini et al. (1992) and Ćalić et al. (2013). The flowers were dried in open air at room temperature in the shade for about 10 days, and then stored in Kraft paper bags until SEM observation. About ten flowers per tree were attached to aluminium stubs using double-adhesive tape and coated with a CRESSINGTON SPUTTER COATER 108 auto for $160 \mathrm{~s}$ at a pressure of $0.1 \mathrm{bar}$ and studied using a Philips ESSEMXL 30 SEM. The specimens were observed at $20 \mathrm{kV}$ and at $1500 \times$ magnification for general observation of pollen morphology and at $2500 \times$ for details of exine ornamentation. 


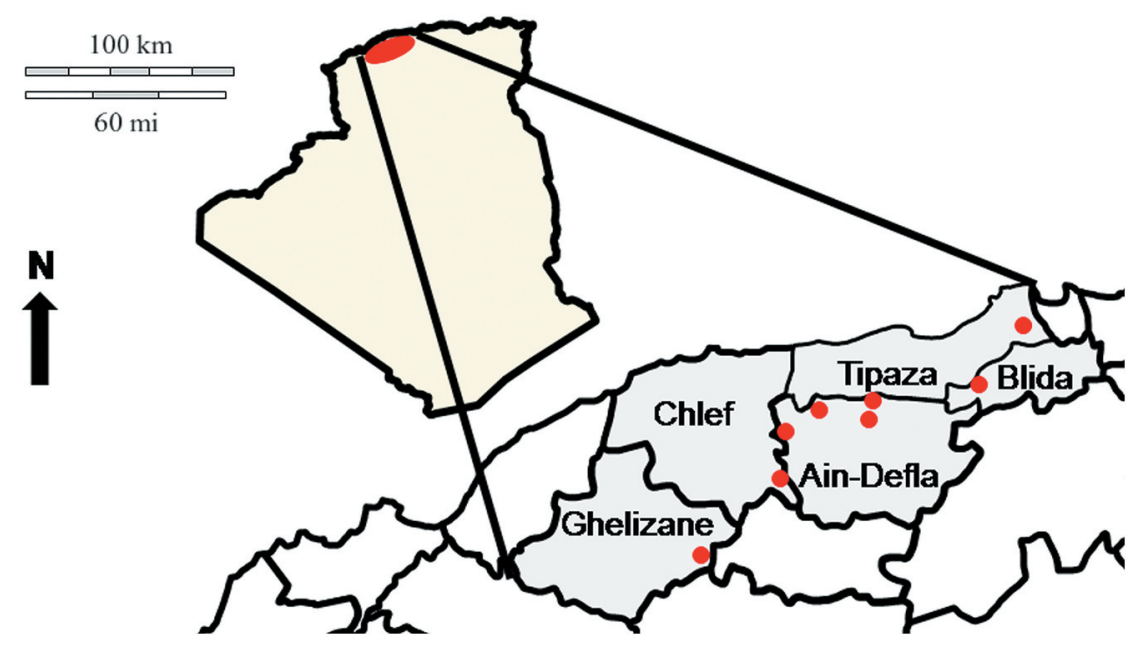

Figure 1. Location of the different sampling areas.

Table I. Population designation, origin and geo-climatic characteristics of the study sites.

\begin{tabular}{|c|c|c|c|c|c|c|c|c|c|c|}
\hline $\begin{array}{l}\text { Population } \\
\text { designation }\end{array}$ & $\begin{array}{c}\text { Population } \\
\text { origin }\end{array}$ & $\begin{array}{l}\text { Alt. } \\
(\mathrm{m})\end{array}$ & Lat. & Long. & $\begin{array}{l}\operatorname{MaxT} \\
\left({ }^{\circ} \mathrm{C}\right)\end{array}$ & $\begin{array}{c}\operatorname{MinT}\left(^{\circ}\right. \\
\mathrm{C})\end{array}$ & $\begin{array}{c}\text { Mean T } \\
\left({ }^{\circ} \mathrm{C}\right)\end{array}$ & $\begin{array}{c}P_{\mathrm{p}} \\
(\mathrm{mm})\end{array}$ & Q3 & $\begin{array}{l}\text { Bioclimatic } \\
\text { stage }\end{array}$ \\
\hline GH & Ghelizane & 201 & 35.82 & 1.13 & 26.94 & 12.50 & 19.72 & 503.80 & 49.79 & Arid very hot \\
\hline Chl & Chelif & 492 & 36.06 & 1.60 & 23.83 & 11.05 & 17.44 & 671.75 & 71.26 & $\begin{array}{l}\text { Semi-arid very } \\
\text { hot }\end{array}$ \\
\hline $\mathrm{ADL} 1$ & Ain-Defla & 667 & 36.34 & 1.78 & 22.36 & 13.44 & 17.90 & 676.54 & 84.78 & $\begin{array}{c}\text { Sub-humid } \\
\text { very hot }\end{array}$ \\
\hline ADL2 & & 231 & 36.25 & 1.88 & 25.66 & 6.05 & 15.85 & 669.46 & 69.34 & Semi-arid mild \\
\hline ADL3 & & 394 & 36.27 & 2.22 & 23.16 & 12.22 & 17.69 & 637.60 & 78.07 & $\begin{array}{l}\text { Semi-arid very } \\
\text { hot }\end{array}$ \\
\hline ADL4 & & 529 & 36.29 & 2.23 & 22.22 & 11.68 & 16.95 & 662.84 & 81.41 & Sub-humid hot \\
\hline B & Blida & 92 & 36.47 & 2.65 & 25.23 & 12.89 & 19.06 & 659.31 & 75.93 & $\begin{array}{l}\text { Semi-arid very } \\
\text { hot }\end{array}$ \\
\hline $\mathrm{T}$ & Tipaza & 110 & 36.65 & 2.79 & 22.52 & 14.68 & 18.60 & 510.81 & 78.41 & $\begin{array}{l}\text { Semi-arid very } \\
\text { hot }\end{array}$ \\
\hline
\end{tabular}

Note: Alt., Altitude; Lat., Latitude; Long., Longitude; $\operatorname{MaxT}\left({ }^{\circ} \mathrm{C}\right)$, maximum temperature; $\operatorname{MinT}\left({ }^{\circ} \mathrm{C}\right)$, minimum temperature; MeanT $\left({ }^{\circ}\right.$ C), mean temperature; $P_{\mathrm{p}}$, precipitation; Q3; Emberger pluviothermic quotient.

\section{Image analysis with Imagef/fiji software}

SEM-micrographs were analysed using ImageJ/ fiji1.46 software for the metric measurements of pollen morphology and exine structure according to Lanza et al. (1996), Messora et al. (2017) and Laaribi et al. (2018) protocols commonly used for the study of olive pollen. Characters used in the analysis follow the definition of Punt et al. (2007) and Hesse et al. (2009), and include polar axis $P$ (in $\mu \mathrm{m}$ ), equatorial axis $E$ (in $\mu \mathrm{m}$ ), pollen ratio $P / E$, pollen size index (PSI) $=(P \times E) / 100$, providing information on both size and shape of the pollen, pollen colpus length PCL (in $\mu \mathrm{m}$ ) and pollen shape factor $(\mathrm{PSF})=(R \times 100)$, where $R$, is the pollen ratio $P / E$. Exine characters include width of the muri $\mathrm{Mw}$ (in $\mu \mathrm{m}$ ), lumina area LA (in $\mu \mathrm{m}^{2}$ ), lumina perimeter $\mathrm{LPm}$ (in $\mu \mathrm{m}$ ), maximum lumina diameter $L$ (in $\mu \mathrm{m}$ ), minimum lumina diameter $W$ (in $\mu \mathrm{m}$ ), lumina ratio $L / W$, mean lumina diameter $\mathrm{Lm}$ (in $\mu \mathrm{m}$ ), lumina equivalent circle diameter $(\mathrm{ECD})=2 \sqrt{ }\left(\frac{\text { area }}{\pi}\right)$, lumina size index $(\mathrm{LSI})=(L \times$ $W) / 100$, lumina shape factor (LSF) $=4 \pi($ area/ perimeter ${ }^{2}$ ) and lumina density $(\mathrm{LD})=$ number of lumina per $100 \mu \mathrm{m}^{2}$.

Twenty-five pollen grains from each tree, equivalent to 75 pollen per site and 600 for all sites, were measured and observed.

\section{Statistical analysis}

Using xlsat software, we carried out a variance analysis followed by a multiple comparison by Duncan's test, a correlation analysis supplemented by regression curves, principal component analysis (PCA) and hierarchical ascending classification (HAC) analysis. 

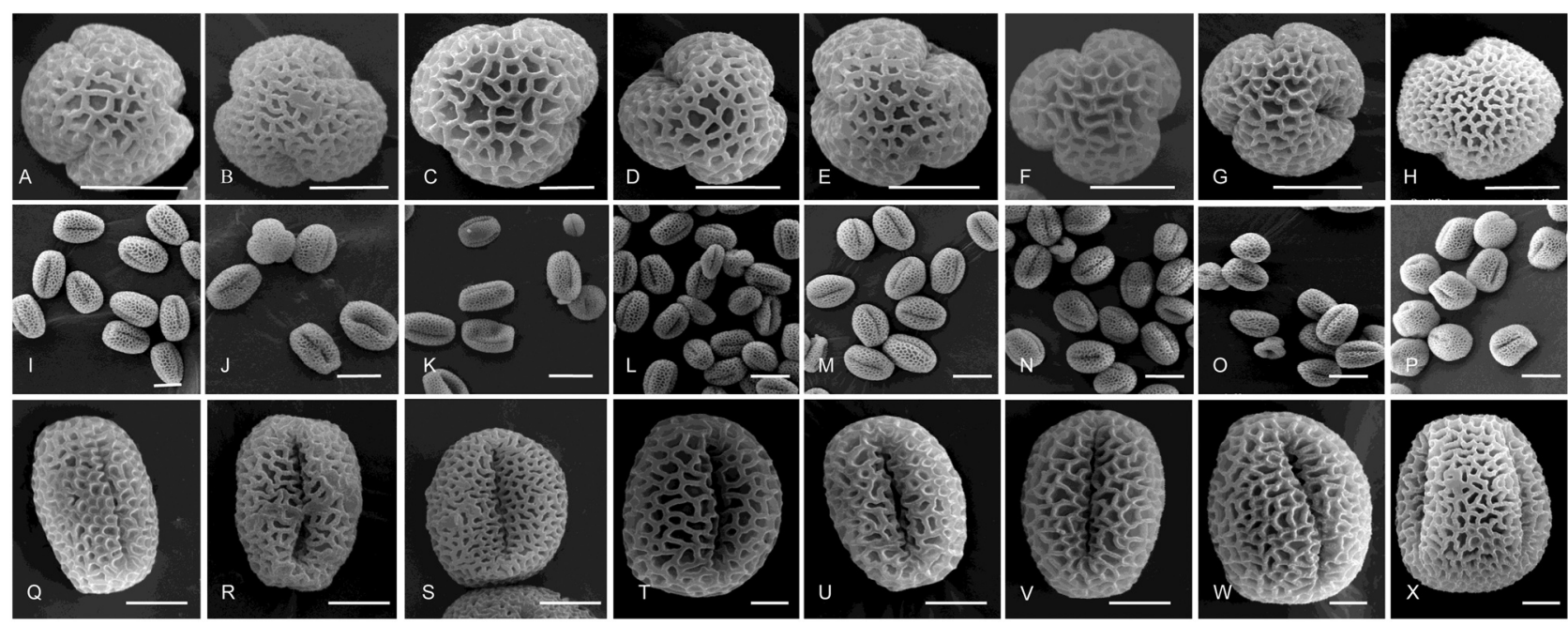

Figure 2. Scanning electron microscope observation of pollen grains from eight different localities under $6500 \times$ magnification. A-H. Polar pollen view. A. (Chl). B. (ADL2). C. (ADL4). D. (ADL1). E. (ADL3). F. (B). G. (T). H. (GH). I-P. Pollen overview. I. (Chl). J. (ADL2). K. (ADL4). L. (ADL1). M. (ADL3). N. (B). O. (T). P. (GH). Q-X. General pollen view. Q. (Chl). R. (ADL2). S. (ADL4). T. (ADL1). U. (ADL3). V. (B). W. (T). X. (GH). Scale bars $-20 \mu \mathrm{m}(\mathrm{I}-\mathrm{P}), 10 \mu \mathrm{m}(\mathrm{A}, \mathrm{B}, \mathrm{D}, \mathrm{E}-\mathrm{H}, \mathrm{Q}-\mathrm{S}, \mathrm{U}, \mathrm{V}), 5 \mu \mathrm{m}(\mathrm{C}, \mathrm{T}, \mathrm{W}, \mathrm{X})$.

\section{Results}

Pollen grains from the eight sites are all tricolpate and trizonocolpate (Figure $2 \mathrm{~A}-\mathrm{H}$ ).

\section{Micromorphometric variability of pollen and exine}

With the exception for $E(p=0.037), P / E(p=0.007)$ and $\operatorname{LD}(p=0.019)$ in the ADL2 population and the $P / E$ ratio in the ADL3 $(p=0.02)$ and T $(p=0.035)$ populations; no intra-population variability in pollen and exine biometry was observed in any of the study populations; for the other parameters tested at the $5 \%$. Nevertheless, the results of pollen and exine biometric parameters indicate a high phenotypic variability between populations (Tables II, III). Indeed, the inter-populations variability is significant at $1 \%$ $(p=0.0001)$, for all parameters tested on pollen morphology. The extreme values for $P$ are obtained by the $\mathrm{GH}$ and $\mathrm{T}$ populations, for $E$ by the ADL3 and T populations and for $P / E$ ratio by ADL4 and GH populations. In addition, the $P / E$ ratio or $(P / E) \times 100$ and $P$ can yield information on two qualitative characteristics (pollen size and shape) (Table II).

Except for the GH population, where the pollen form is prolate-spheroidal or subprolate, the pollen form of the other populations is prolate. The GH population is the most diverse. Pollen from all eight populations belongs to the 'small size' category; according to the terminology of Halbritter et al. (2018), where the pollen size is between 3.14 and 4.28 and the size of the largest diameter is between $10 \mu \mathrm{m}$ and $25 \mu \mathrm{m}$ (Figure 2I-X, Table II).
For the length of the colpus, the maximum and minimum values were observed from the $\mathrm{T}$ and $\mathrm{GH}$ populations, respectively (Table II).

For the 11 exine parameters, the inter-populations variability is significant at the threshold of $1 \%(p=0.0001)$. Most of the extreme values of the exine parameters were produced by ADL4 and ADL1 populations, respectively, for the minimum and maximum values: $\mathrm{LA}, \mathrm{LPm}, L, W, \mathrm{ECD}$, LSI and $\mathrm{Mw}$. The ADL1 population also generated the highest mean for $\mathrm{Lm}$, but the lowest value was observed for the GH population (Table III). The highest LD parameter was recorded from the GH population, while the $T$ population gave the lowest lumina density (Figure 3, Table III). The highest and lowest LSF values were observed in the $\mathrm{B}$ and $\mathrm{Chl}$ populations, respectively. The three populations (ADL1, ADL3 and T) are at the top of Duncan's ranking and fall into Group A for almost all of the exine parameters (Table III).

\section{Results of multivariate analysis of pollen and exine parameters}

To avoid redundancy and confusion in the interpretation of results, we used a combination of two multivariate analysis models namely, PCA and HAC.

Results of the principal component analysis (PCA). - A reduced, centred and standardised PCA was carried out. The elbow method was used to select factors and the optimal number of groups. According to PCA results, $92.86 \%$ of the total variability can be explained 

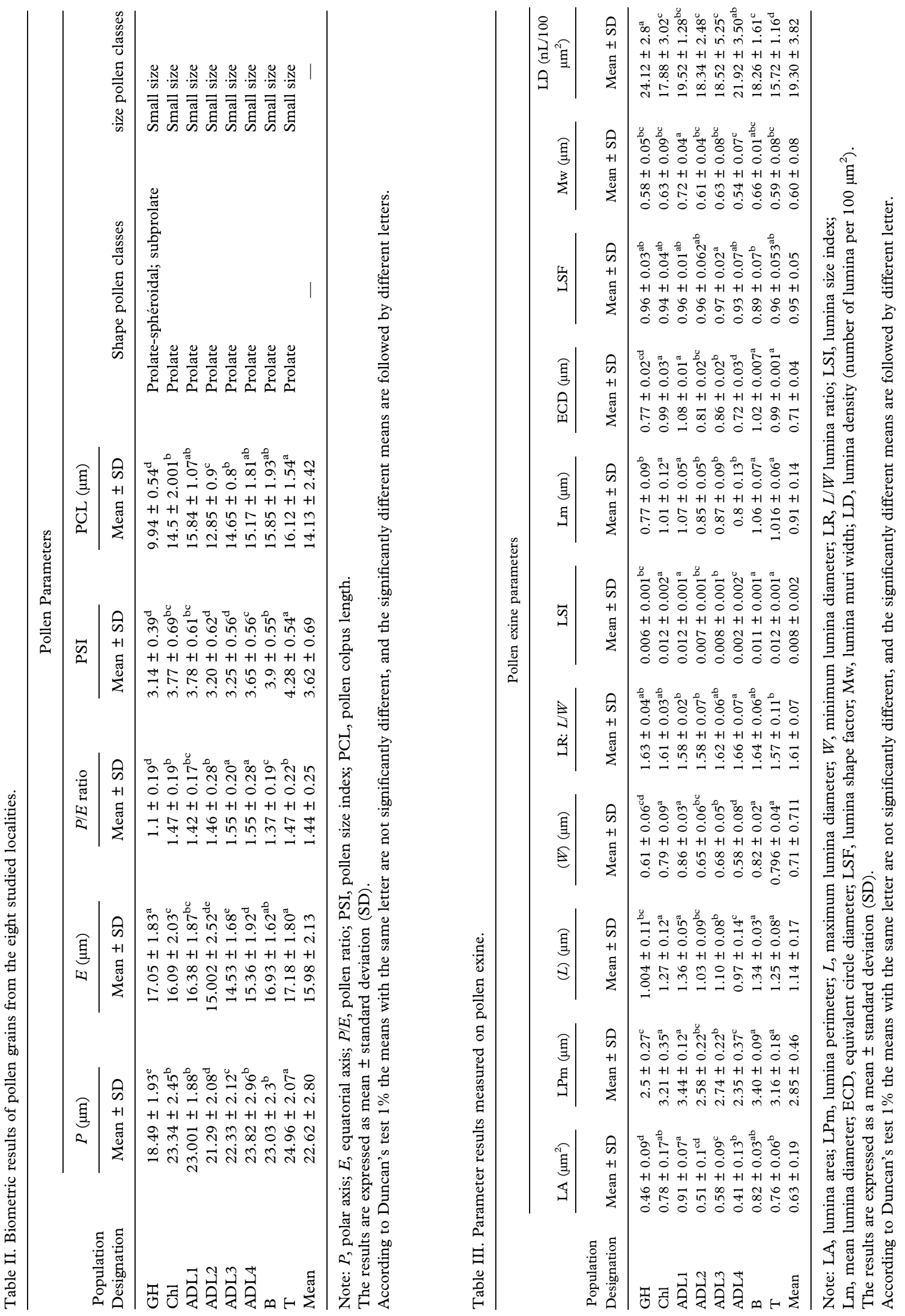

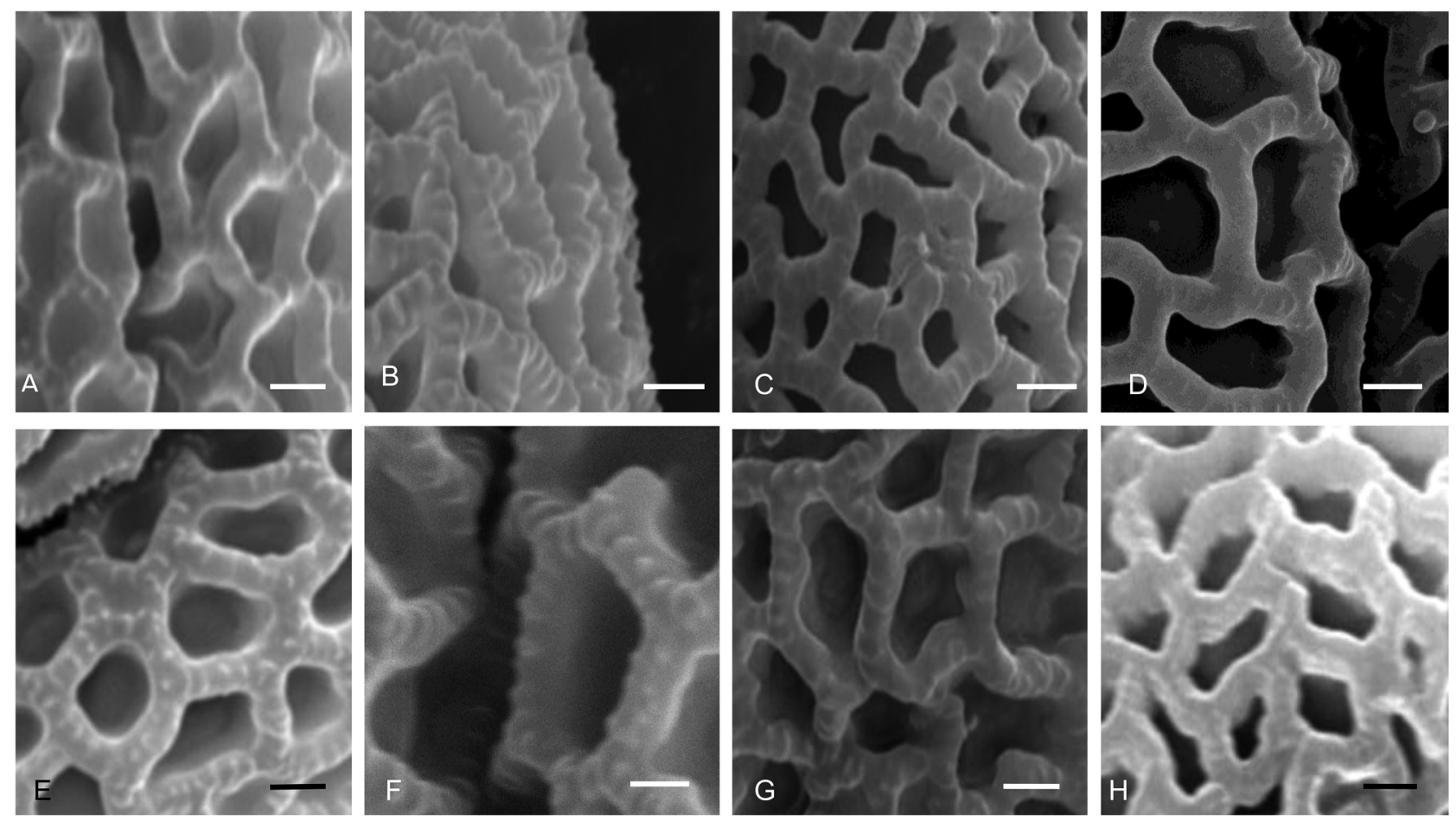

Figure 3. Scanning electron microscope observation of the exine pollen viewed under $2500 \times$ magnification. A. (Chl). B. (ADL2). C. (ADL4). D. (ADL1). E. (ADL3). F. (B). G. (T). H. (GH). Scale bars $-2 \mu \mathrm{m}$.

by three factors: F1, F2 and F3. Most of the information was obtained by $\mathrm{F} 1(63.72 \%)$ whereas those revealed by $\mathrm{F} 2$ are only $15.93 \%$ and $13.21 \%$ by F3. Factor $\mathrm{F} 1$ represents exine while factor $\mathrm{F} 2$ represents pollen (Figure 4A).

A

Variables (axes F1 and F2:79.64\%)

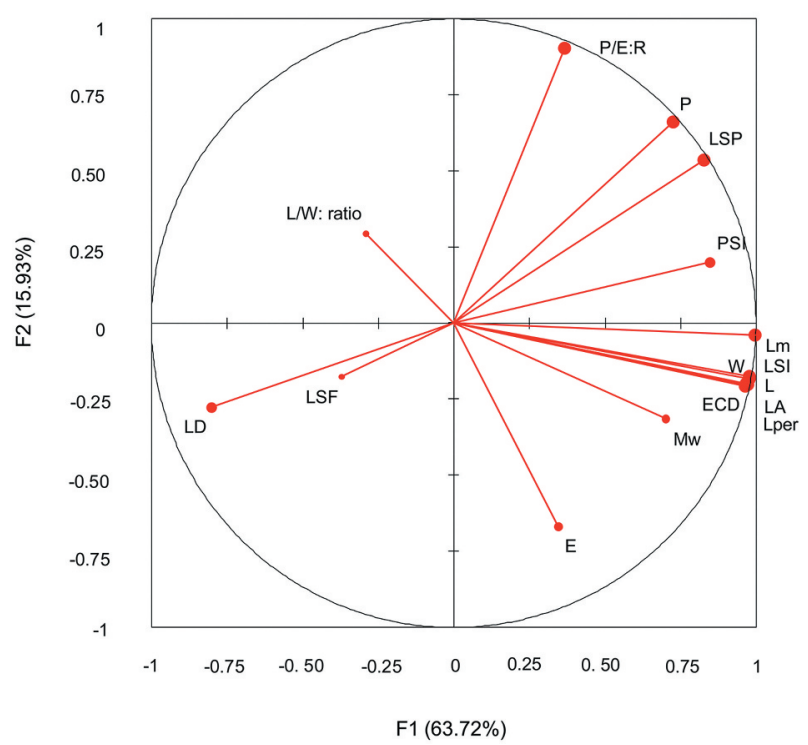

The pollen parameters $E$ and $P / E$ ratio are represented by $\mathrm{F} 2$; those of exine: $L / W$ and LSF ratio are represented by $\mathrm{F} 3$. With the exception of $\mathrm{LD}$ which is positioned on the left side of $\mathrm{F} 1$, the other pollen and exine parameters are on the right side of $\mathrm{F} 1$ (Figure 4A).

Figure 4. Principal component analysis. A. Projection of the variables measured on pollen and exine in the F1 and F2 axes. B. Projection of the populations in the F1 and F2 axes. Populations are GH, Chl, ADL1, ADL2, ADL3, ADL4, B and T. Abbreviations: $P$, polar axis; E, equatorial axis; $P / E$, pollen ratio; PSI, pollen size index; PCL, pollen colpus length; LA, lumina area; LPm, lumina perimeter; $L$, maximum lumina diameter; $W$, minimum lumina diameter; LR, $L / W$ lumina ratio; LSI, lumina size index; Lm, mean lumina diameter; ECD, equivalent circle diameter; LSF, lumina shape factor; $\mathrm{Mw}$, lumina muri width; $\mathrm{LD}$, lumina density (number of lumina per $100 \mathrm{\mu m}^{2}$ ). 
Except for ADL4 population, which corresponds to F2, F1 represents the other populations (Figure 4B). In terms of factors, $\mathrm{F} 1$ and $\mathrm{F} 2$, the populations are divided into three groups: the first group (G1) contains three populations (Chl, ADL2 and ADL4), the second group (G2) represents four populations (ADL1, ADL3, B and T) and the third (G3) includes of a single population $(\mathrm{GH})$ (Figure $4 \mathrm{~B})$.

Results of the hierarchical ascending classification (HAC). - The HAC method used allowed classifying the study populations into three groups GI, GII and GIII (Figures 5, 6).

\section{Environmental factors}

The 35-year averages of climate data (maximum temperature, average temperature, minimum temperature and sum of annual precipitation), collected at the weather stations closest to the study sites, were corrected for the elevation of the sites (Table I).

According to the ombrothermal diagrams of Bagnouls and Gaussen (1953) and the $P_{\mathrm{p}} / T$ ratio (monthly arid-humidity Rivas-Martinez 1987), the duration of drought during the year varies from one location to another; it may start very early in the year or late.
8According to the Bagnouls and Gaussen method, the results show that drought may last from 3 months up to 5 months. The drought period may start from the second week of May to mid-October (Figure 7). However, according to Rivas-Martinez (1987), the dry period may last from 6 to 8 months depending on the study area.

\section{Relationship between pollen parameters}

At a threshold of $5 \%$, the polar axis parameter $(P)$ is positively and significantly related to PSI and PCL. At the same threshold and in the same direction as the first case, PCL, is significantly correlated with PSI (Table IV).

\section{Relationship between exine parameters}

The correlations between some exine parameters are very significant and positive at the threshold of $5 \%$. The ' $r$ ' values are $>0.99$ (Table IV).

\section{Relationship between pollen and exine parameters}

Between the parameters (PCL and Lm; PSI and Lm) positive and highly significant relationships are observed. Negatively significant relationships

\section{Dendrogram}

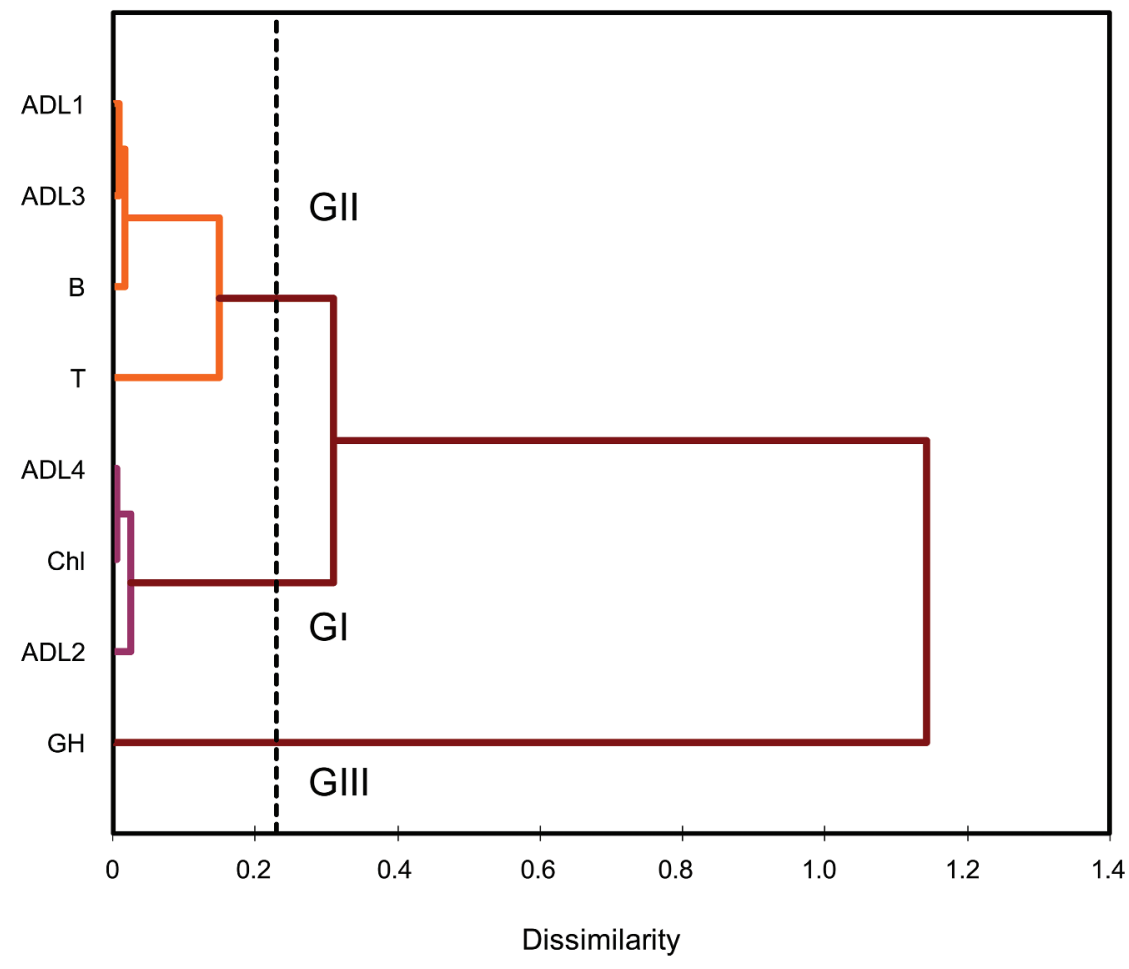

Figure 5. Cluster obtained by the hierarchical ascending classification analysis on pollen and exine micro-morphometric characters. Populations are $\mathrm{GH}, \mathrm{Chl}$, ADL1, ADL2, ADL3, ADL4, B and T. 

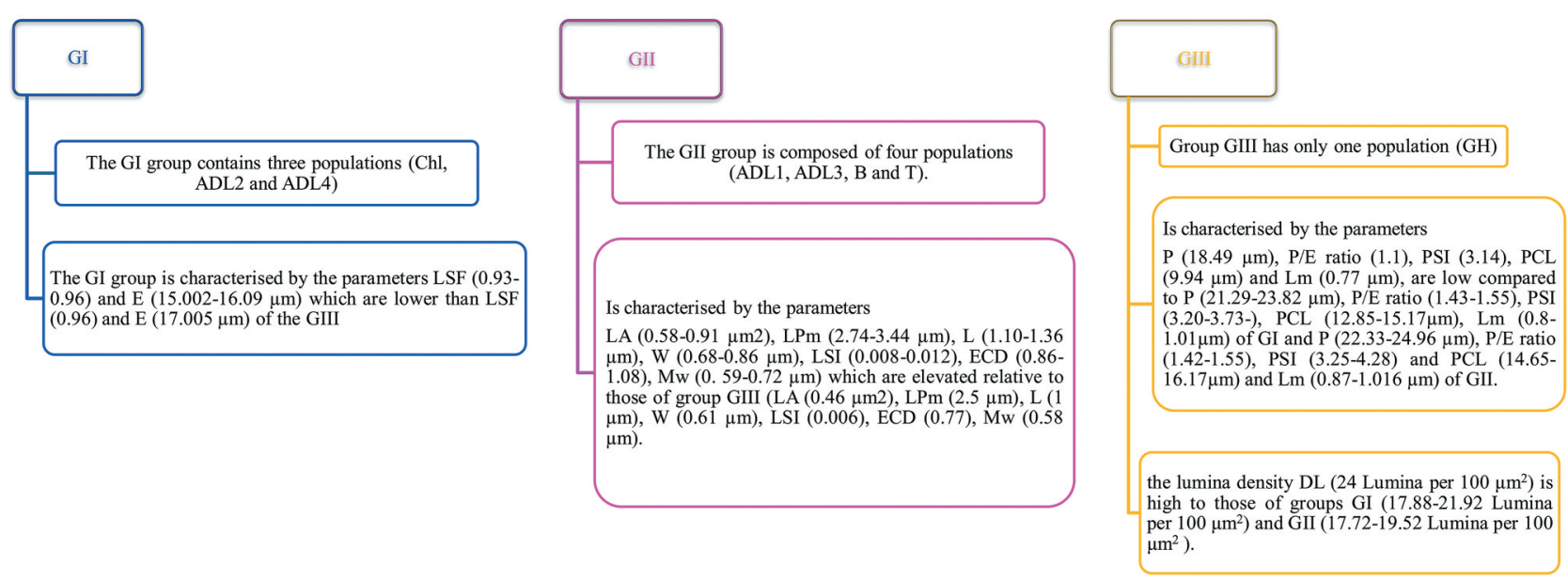

Figure 6. Characteristics of groups obtained by multivariate analysis groups are GI, GII and GIII. Abbreviations: $P$, polar axis; $P / E$, pollen ratio; PSI, pollen size index; PCL, pollen colpus length; LA, lumina area; LPm, lumina perimeter; $L$, maximum lumina diameter; $W$, minimum lumina diameter; LSI, lumina size index; Lm, mean lumina diameter; LD, lumina density (number of lumina per $100 \mu \mathrm{m}^{2}$ ).

are observed between $P$ and LD. PSI and PCL are correlated with almost every parameter of the exine. This correlation is negative with LD and positive with the other parameters (Table IV).

\section{Geo-climatic impact on pollen and exine parameters}

The geo-climatic interaction between pollen and its exine parameters was tested by the slope of the regression model $y=a x+b$ and supplemented by the regression curves and the coefficient of determination (Figure 8).

Latitude and longitude are strongly and positively related to (P, PSI, and PCL). However, with the exception of $\mathrm{LD}$ and $\mathrm{Lm}$, which are related to latitude, the remaining exine parameters are not related to the geo-climatic parameters (Figure 8, Table V).

Negatively significant to very highly significant relationships were recorded among pollen parameters $(P /$ $E$ ratio $[\mathrm{r}=-0.755]$, PCL $[r=-0.787], P$ $[\mathrm{r}=-0.855])$ and maximum temperature on the one hand, and between the warmest month's maxima temperature and PCL $(r=-0.97), P(r=-0.88)$ and PSI $(r=-0.887)$, on the other hand. Besides that, positively significant correlations were found between the minima temperature of the coldest month and PSI $(r=0.740)$, and between the average temperature and $E(r=0.742)$ (Figure 8, Table V). No significant relationship is recorded between the exine characteristics and the climate of the study sites.

\section{Discussion}

The populations from the eight study areas have trizonocolpate pollen grains that show considerable similarity in terms of size and shape; most of the pollen grains, from each population, are small and prolate as also previously observed in pollen of olive cultivars by Lanza et al. (1996), Javadi and Arzani (2001) and Koubouris et al. (2012). However, Ribeiro et al. (2008) reported three types of shapes; elliptic, subprolate and spheroidal-prolate in 20 olive cultivars grown in Portugal. Furthermore, no intra-population variability was detected in the populations from ADL1, ADL4, GH, Chl, B and $\mathrm{T}$ areas. However, low intra-population variability in $E, P / E$ ratio, and PSI parameter was noted for the ADL2 site and in the $P / E$ ratio parameter for the population of ADL3.

High intra-specific variability in Olea europaea subsp. europaea var. sylvestris) was, however, observed for pollen and exine parameters according to the geo-climatic conditions of the study areas. The use of multivariate analysis HAC and PCA was very essential for a clearer vision of inter-populations variability. The results of the HAC and PCA analyses corroborate (Figures 4,5 ). Thus, the eight populations tested were divided into three groups or morphotypes.

It should be noted that earlier studies have indicated that intra-specific polymorphism may be induced by two factors, which may be internal or external, or a combination of both (Derridj et al. 1991; El Ghazali et al. 1997; Belhadj et al. 2007). Internal factors are varied and are related to the species itself. External factors are related to the environment in which the different populations of the species have evolved. Environment factors may be geo-climatic (altitude, latitude, longitude, temperature, precipitations) or soil composition. The soil 
A

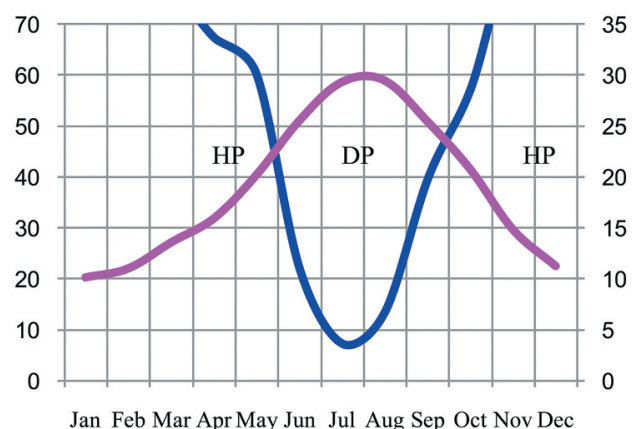

C

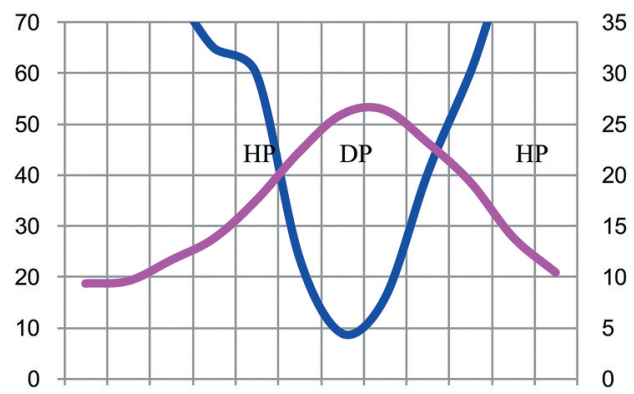

Jan Feb Mar Apr May Jun Jul Aug Sep Oct Nov Dec

E

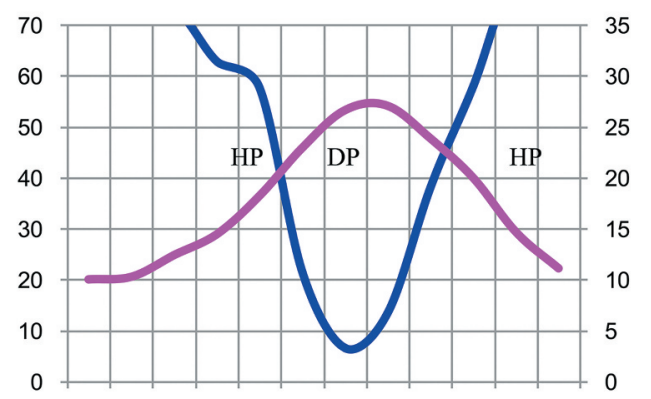

Jan Feb Mar Apr May Jun Jul Aug Sep Oct Nov Dec

G

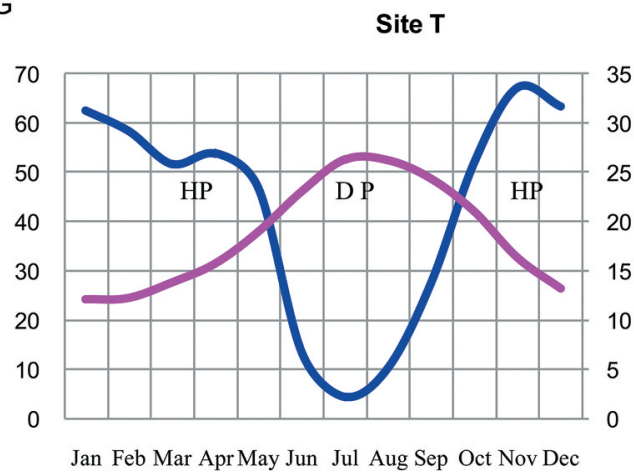

B

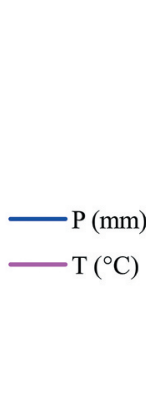

$\underset{-\mathrm{P}(\mathrm{mm})}{-\mathrm{T}\left({ }^{\circ} \mathrm{C}\right)}$

D

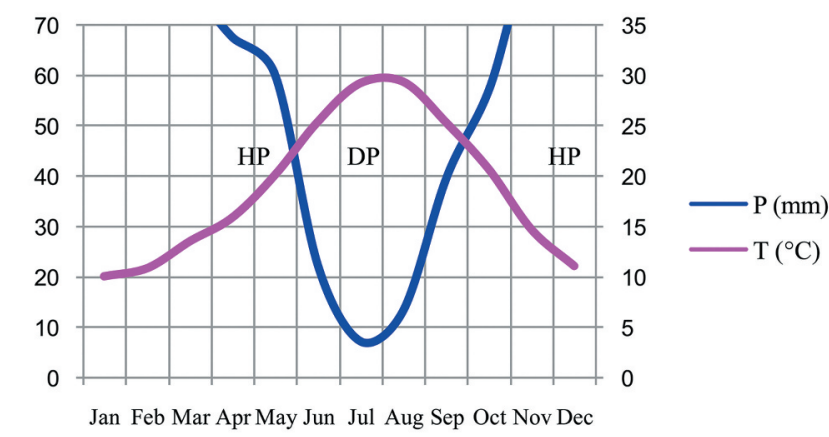

Site ADL1

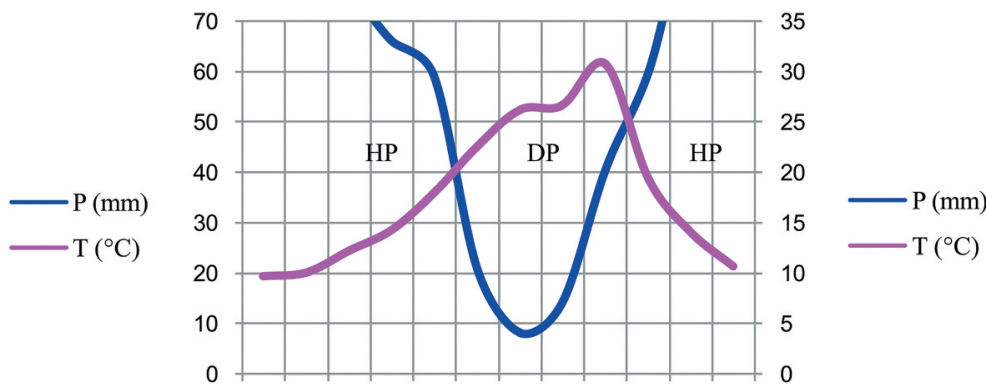

Jan Feb Mar Apr May Jun Jul Aug Sep Oct Nov Dec

$\mathrm{F}$

Site B

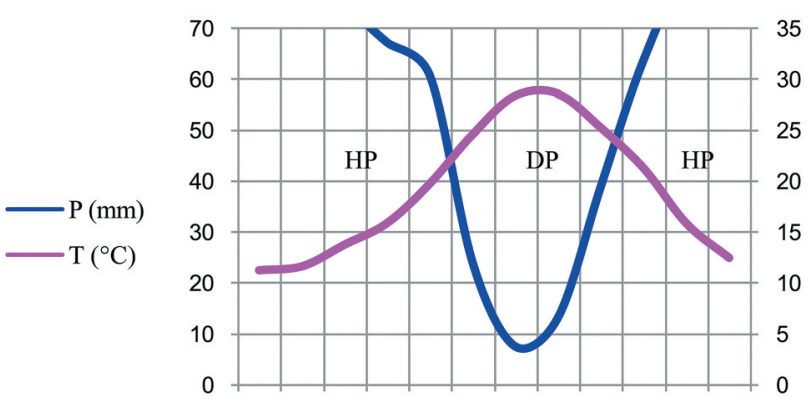

Jan Feb Mar Apr May Jun Jul Aug Sep Oct Nov Dec

$\mathrm{H}$

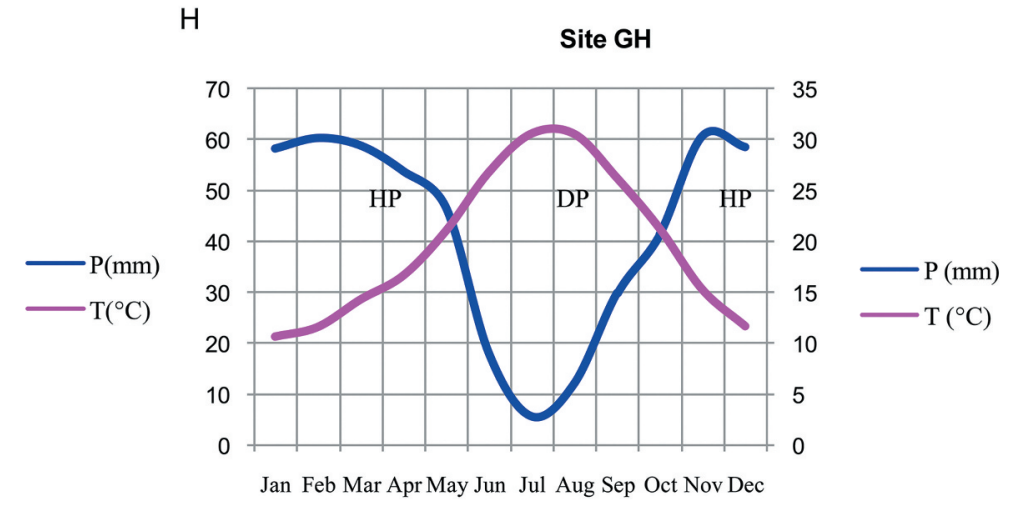

Figure 7. Ombrothermic diagram of Bagnouls and Gaussen method for a period of 35 years. Abbreviations: DP, dry period; HP, humid period; $P$, precipitation; $T$, temperature. 


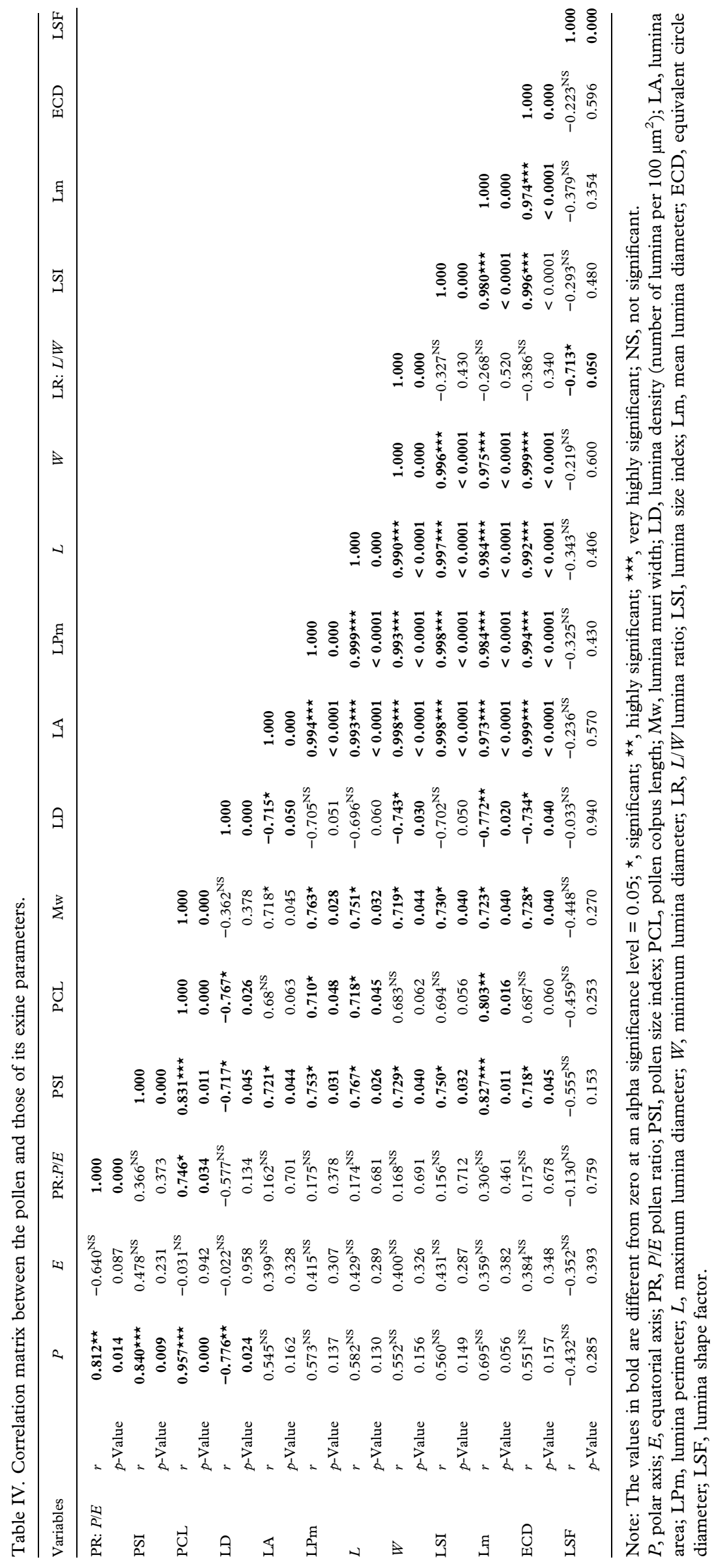



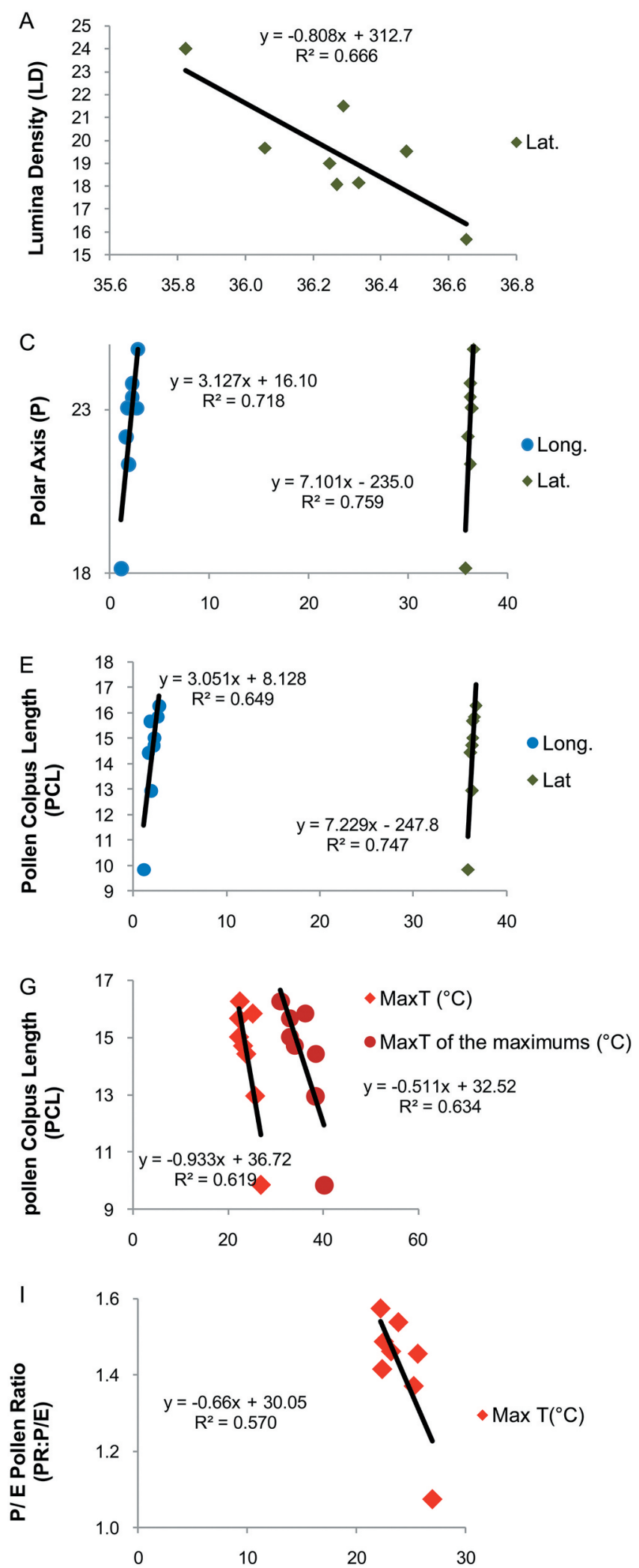

Figure 8. Regression curves obtained between the different geo-climatic parameters and the pollen and its exine parameters. Abbreviations: Lat., latitude; Long., longitude; $\operatorname{MaxT}\left({ }^{\circ} \mathrm{C}\right)$, maximum temperature; MaxT of the maximums $\left({ }^{\circ} \mathrm{C}\right)$, the average temperature of the maxima of the warmest month; $\operatorname{MinT}$ of the minimums $\left({ }^{\circ} \mathrm{C}\right)$, the average temperature of the minima of the coldest month; MeanT $\left({ }^{\circ} \mathrm{C}\right)$, mean temperature; LD, lumina density (number of lumina per $100 \mu \mathrm{m}^{2}$ ); Lm, mean lumina diameter; $P$, polar axis; PSI, pollen size index; $\mathrm{PCL}$, pollen colpus length; $\mathrm{PR}, P / E$ pollen ratio; $E$, equatorial axis.
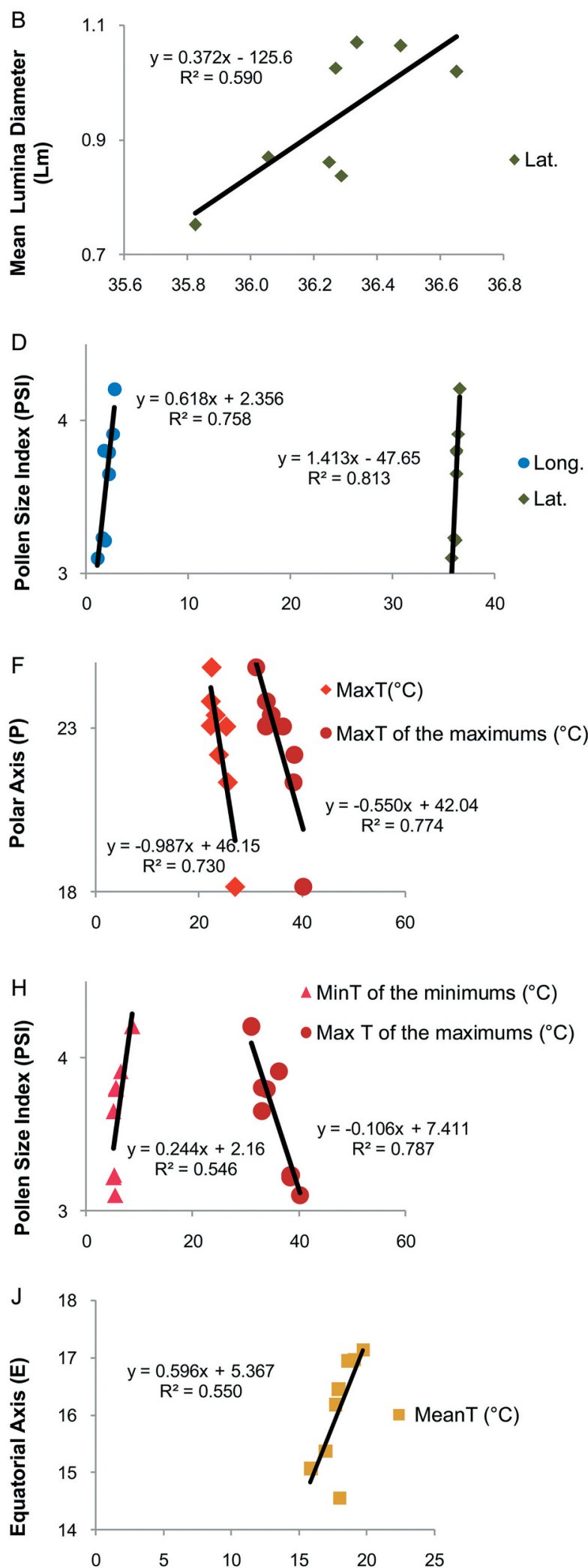
Table V. Correlations between pollen and exine biometrics parameters with geo-climatic parameters.

\begin{tabular}{|c|c|c|c|c|c|c|c|c|}
\hline \multirow{2}{*}{\multicolumn{2}{|c|}{$\begin{array}{c}\text { Geo-climatics } \\
\text { parameters }\end{array}$}} & \multicolumn{5}{|c|}{ Pollen parameters } & \multicolumn{2}{|c|}{ Exine parameters } \\
\hline & & \multirow{2}{*}{$\frac{P}{0.872^{\star \star \star}}$} & \multirow{2}{*}{$\frac{E}{0.233^{\mathrm{NS}}}$} & \multirow{2}{*}{$\frac{\text { PR: } P / E}{0.540^{\mathrm{NS}}}$} & \multirow{2}{*}{$\frac{\text { PSI }}{0.902^{\star \star \star}}$} & \multirow{2}{*}{$\frac{\text { PCL }}{0.865^{\star \star \star}}$} & \multirow{2}{*}{$\frac{\mathrm{LD}}{-0.816^{\star \star}}$} & \multirow{2}{*}{$\frac{\mathrm{Lm}}{0.768^{\star \star}}$} \\
\hline Latitude & $r$ & & & & & & & \\
\hline & $p$-Value & 0.005 & 0.578 & 0.167 & 0.002 & 0.006 & 0.013 & 0.026 \\
\hline \multirow[t]{2}{*}{ Longitude } & $r$ & 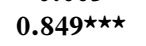 & $0.229^{\mathrm{NS}}$ & $0.526^{\mathrm{NS}}$ & $0.871^{\star \star \star}$ & $0.806^{\star \star}$ & $-0.678^{\mathrm{NS}}$ & $0.668^{\mathrm{NS}}$ \\
\hline & $p$-Value & 0.008 & 0.586 & 0.180 & 0.005 & 0.016 & 0.065 & 0.070 \\
\hline \multirow[t]{2}{*}{$\operatorname{MaxT}\left({ }^{\circ} \mathrm{C}\right)$} & $r$ & $-0.855^{\star \star \star}$ & $0.172^{\mathrm{NS}}$ & $-0.755^{\star}$ & $-0.650^{\mathrm{NS}}$ & $-0.787^{\star \star}$ & $0.585^{\mathrm{NS}}$ & $-0.493^{\mathrm{NS}}$ \\
\hline & $p$-Value & 0.007 & 0.684 & 0.030 & 0.081 & 0.020 & 0.128 & 0.214 \\
\hline \multirow[t]{2}{*}{ MeanT $\left({ }^{\circ} \mathrm{C}\right)$} & $r$ & $-0.272^{\mathrm{NS}}$ & $0.742^{\star}$ & $-0.655^{\mathrm{NS}}$ & $0.159^{\mathrm{NS}}$ & $-0.167^{\mathrm{NS}}$ & $0.238^{\mathrm{NS}}$ & $0.090^{\mathrm{NS}}$ \\
\hline & $p$-Value & 0.514 & 0.035 & 0.078 & 0.706 & 0.692 & 0.571 & 0.833 \\
\hline \multirow{2}{*}{$\begin{array}{l}\text { Minimum of the } \\
\text { minima } T\left({ }^{\circ} \mathrm{C}\right)\end{array}$} & $r$ & $0.484^{\mathrm{NS}}$ & $0.565^{\mathrm{NS}}$ & $0.049^{\mathrm{NS}}$ & $0.740^{\star}$ & $0.458^{\mathrm{NS}}$ & $-0.635^{\mathrm{NS}}$ & $0.489^{\mathrm{NS}}$ \\
\hline & $p$-Value & 0.224 & 0.144 & 0.909 & 0.036 & 0.254 & 0.091 & 0.219 \\
\hline \multirow{2}{*}{$\begin{array}{l}\text { Maximum of the } \\
\text { maxima } T\left({ }^{\circ} \mathrm{C}\right)\end{array}$} & $r$ & $-0.880^{\star \star \star}$ & $-0.221^{\mathrm{NS}}$ & $-0.553^{\mathrm{NS}}$ & $-0.887 \star \star \star$ & $-0.797 \star \star$ & $0.673^{\mathrm{NS}}$ & $-0.643^{\mathrm{NS}}$ \\
\hline & $p$-Value & 0.004 & 0.599 & 0.155 & 0.003 & 0.018 & 0.067 & 0.086 \\
\hline
\end{tabular}

Note: Values in bold are different from zero at an alpha significance level $=0.05$.

$\star$, significant; ${ }^{\star \star}$, highly significant; ${ }^{\star \star \star}$, very highly significant; NS, not significant; $r$, correlation coefficient.

$P$, polar axis; $E$, equatorial axis; PR, P/E pollen ratio; PSI, pollen size index; PCL, pollen colpus length; Lm, mean lumina diameter; LD, lumina density (number of lumina per $100 \mu \mathrm{m}^{2}$ ).

MaxT, maximum temperature; MeanT, mean temperature.

may have an effect on plant's nutrition (El Ghazali et al. 1997).

Furthermore, according to our results, each morphotype includes populations from localities with geo-climatic characteristics that seem to have an effect on phenotypic expression on the one hand, and on the adaptability of the population on the other hand. Indeed, the study areas are geo-climatically different from one another (Table I) and as a result, there is no single pattern for drought, periods of drought appear and disappear at different periods of the year and persist for varying lengths of time (Figure 7).

The first morphotype was collected from Chl, ADL2 and ADL4 site. The ADL4 site has the lowest minimum temperature and the highest annual precipitation compared to other sites. The second morphotype were collected from ADL1, ADL3, B and $\mathrm{T}$. These sites are characterised by a more or less low maximum temperature, a somehow high minimum temperature, an intermediate average mean temperature and an average annual precipitation. Finally, the GH site, which is home to the third morphotype, stands out from the other sites by having the lowest latitude and longitude, the highest maximum and average temperatures and low annual precipitation (Table I).

With respect to the geographical impact on variability in our studied species (Olea europaea subsp. europaea var. sylvestris), three pollen characteristics and two exine parameters seem to be affected by latitude and longitude (Figure 8, Table V).

Our results show that for an increase in latitude by one decimal degree, $\mathrm{LD}$ decreases by $0.808 \mu \mathrm{m}$ and
Lm, P, PSI, PCL, increase by $0.372,7.107,1.413$ and $7.229 \mu \mathrm{m}$, respectively. For one decimal degree increase in longitude, $P$, PSI, PCL increase by 3.127 , 0.618 and $3.051 \mu \mathrm{m}$, respectively, (Figure $8 \mathrm{~A}-\mathrm{E}$ ). Altitude has no effect on the inter-populations variability of our species (Olea europaea subsp. europaea var. sylvestris). Similar results were obtained by John and Birks (1978) on the geographical effect on pollen size and shape of Picea abies (L.) Karsten, and by Lobreau-Callen (1975) on the dimensional variations of pollen of the genus Ilex (Aquifoliaceae). This author was able to demonstrate that within each species or variety, measurements differ according to geographical distribution and more precisely according to the gradient of latitude. Derridj et al. (1991) and Belhadj et al. (2007) reported the same results for the Algerian Atlas cedar (Cedrus atlantica Manetti) and Pistacia atlantica pollen, respectively.

Climate can also affect pollen parameters (Porch \& Jahn 2001) and in particular temperatures (Kurtz \& Liverman 1958). In our case, the effect was observed for the maximum temperature, the average temperature of the maxima of the warmest month, and to a lesser degree for the average temperature of the minima of the coldest month and mean temperature (Figure 8 , Table V).

The correlations noted between some of the parameters and the climatic data show that the variation of five pollen parameters is related to at least one of the temperatures considered in this work. In fact, any increase in the maximum temperature by $1^{\circ} \mathrm{C}$ results in a decrease in $P$ by $0.987 \mu \mathrm{m}$ (Figure $8 \mathrm{~F}$ ), PCL by $0.933 \mu \mathrm{m}$ (Figure 8G) and by 0.66 in $P / E$ ratio (Figure 8I). Similarly, an increase in the average tem- 
perature of the warmest month's maxima by $1^{\circ} \mathrm{C}$, results in a decrease of $P$ by $0.55 \mu \mathrm{m}$ (Figure $8 \mathrm{~F}$ ), by $0.511 \mu \mathrm{m}$ for PCL (Figure 8G) and by $0.106 \mu \mathrm{m}$ for PSI (Figure $8 \mathrm{H}$ ). The same conclusions can be made for the average minima temperature of the coldest month and the mean temperature where increases of $1^{\circ} \mathrm{C}$ can cause PSI and $E$ to increases by 0.244 (Figure $8 \mathrm{H}$ ) and $0.596 \mu \mathrm{m}$ (Figure 8J), respectively.

Ejsmond et al. (2015) found that high temperatures associated with high humidity generate large pollen, whereas in our case, high temperatures accompanied by low precipitation generate small sized pollen. Therefore, humidity is the main parameter that can have an effect on pollen size. However, precipitation does not have a direct effect on the variability of pollen and exine characteristics, but the monthly aridity-moisture $\left(P_{\mathrm{p}} \leq 2 T\right.$ on a monthly scale, Rivas-Martinez [1987]) of the study sites has a significant effect. It is also important to note that the duration of the dry period during the year together with the time and intensity of its occurrence has a determinant effect on the morphology and size of the pollen. Indeed, according to the ombrothermal diagrams of Bagnouls and Gaussen (1953) based on a 35year period, the duration of the drought during the year varies from one area to another; it may appear very early in the year or even very late. The drought period can persist for 15 to 20 weeks. It can start as early as the second week of May and last until mid-October (Figure 7).

The morphotype from a site with high temperature, low humidity associated with a long dry period (GH site) is characterised by a small size, low LA and high $\mathrm{LD}$ and vice versa (Figures $2 \mathrm{H}, 3 \mathrm{H}$ ).

One can see from the strong correlations between the pollen parameters and those of the ultra-structure of exine (Table IV), without a direct link between the latter and the characteristics of the environment; that the pollen of the oleaster exhibits an adaptation to the latitude, longitude and temperature gradient of its environment by adopting various phenotypes by modulation of the exine. Indeed, it seems that the ultrastructure of the exine fulfils, through the geometrical structure of its lumina, the function of extending and shrinking the latter according to the gradient of some environmental elements. This function allows for certain flexibility with regard to geo-climatic changes leading to the general phenotypic change of the pollen, which can be controlled by the parameters of the exine. These parameters may be: LA, LPm, $L, W$, LSI, ECD and Lm. We can infer from these findings that through exine, these wild populations have exhibited an adaptation to the conditions of their native environment.
This leads us to think that the variability of LD is only the result of variation in the LA of the lumina, and therefore both parameters reflect the same adaptive means to a particular abiotic parameter such as a lack of water or indirectly as a temperature increase provoking a demand for water.

\section{Conclusions}

The results showed high inter-populations variability. Our observations suggest that, the correlations connecting the exine parameters to each other on one side and to those of pollen on the other; may lead one to think without causation that changes in the size and shape of pollen could be a mechanism for adapting pollen to different environments. It seems that exine structure is of importance for resilience to aridity, by decreasing the LA of the exine and thereby decreasing the size and shape of the whole pollen. From these results it can be deduced that pollen micro-morphological parameters and exine are good markers and their variation may have a genetic origin, suggesting a genetic adaptation that must be evaluated and highlighted. The exploitation of the olive grove as a crop wild relative can supplement the olive tree, by enhancing its characteristics and enabling it to conquer other areas, in particular for varieties that are less adapted to certain geo-climatic conditions and whose economic benefits are not negligible.

\section{Acknowledgements}

The authors thank HALLOUZ Faiza from Water and Environmental Engineering Laboratory, ENSH, Soumaa, Blida (Algeria), for completing the climatic data.

\section{Disclosure statement}

No potential conflict of interest was reported by the authors.

\section{ORCID}

Khedidja Khouatmiani http://orcid.org/0000-00026541-076X

Safia Belhadj http://orcid.org/0000-0002-9732-6474

Alain Tonetto http://orcid.org/0000-0002-4306-8641

Axel Assie http://orcid.org/0000-0001-8405-7095

fean Philippe Mevy http://orcid.org/0000-0001-53760810

Thierry Gauquelin http://orcid.org/0000-0001-8078-

7576 


\section{References}

Abood AA, Al-Ansari AM, Migdadi HM, Okla MK, Assaeed AM, Hegazy AK, Alshameri AM, Khan MA. 2017. Molecular and phytochemical analysis of wild type and olive cultivars grown under Saudi Arabian environment. 3 Biotech 7: 289. doi:10.1007/s13205-017-0920-5.

Alba V, Bisignano V, Alba E, De Stradis A, Polignano G. 2011. Effects of cryopreservation on germinability of olive (Olea europaea L.) pollen. Genetic Resources and Crop Evolution 58: 977. doi:10.1007/s10722-011-9736-z.

Ateyyeh AF. 2009. Storing pollen of two olive cultivars:'Rasie'and 'Nabali Baladi'. International Journal of Fruit Science 9: 282-293. doi:10.1080/15538360903245253.

Bagnouls F, Gaussen H. 1957. Les climats biologiques et leur classification. Annales de Géographie 355: 193-220. doi:10.3406/geo.1957.18273.

Bartolini S, Minnocci A, Vitagliano C. 1992. Morphological studies on pollen in some clones of olive cv. Leccino. Agricoltura mediterranea (Ospedaletto) 122: 282-286.

Belhadj S, Derridj A, Civeyrel L, Gers C, Aigouy T, Otto T, Gauquelin T. 2007. Pollen morphology and fertility of wild Atlas pistachio (Pistacia atlantica Desf., Anacardiaceae). Grana 46: 148-156. doi:10.1080/00173130701520310.

Besnard G, Bervillé A. 2000. Multiple origins for Mediterranean olive (Olea europaea L. ssp. europaea) based upon mitochondrial DNA polymorphisms. Comptes Rendus de l'Académie des Sciences-Series III-Sciences de la Vie 323: 173-181.

Bouarissa C. 2010. Plantation d'un million d'hectares d'oliviers d'ici la fin de 2014. Journal Liberté Algérie: 4. https://fr.cala meo.com/read/00010955157ebfcb89f1b; accessed 2020.

Breton CM, Warnock P, Bervillé AJ. 2012. Origin and history of the olive. In: Olive Germplasm-The Olive Cultivation, Table Olive and Olive Oil Industry in Italy. London: IntechOpen.

Ćalić D, Devrnja N, Kostić I, Kostić M. 2013. Pollen morphology, viability, and germination of Prunus domestica cv. Požegača. Scientia Horticulturae 155: 118-122. doi:10.1016/j. scienta.2013.03.017.

Derridj A, Cadeac F, Durrieu G. 1991. Etude de la variabilité géographique des dimensions des pollens du cèdre de l'Atlas (Cedrus atlantica Manetti) en Algérie. Bulletin de la Société Botanique de France Lettres Botaniques 138: 215-230. doi:10.1080/01811797.1991.10824923.

Ejsmond MJ, Ejsmond A, Banasiak Ł, Karpińska-Kołaczek M, Kozłowski J, Kołaczek P. 2015. Large pollen at high temperature: An adaptation to increased competition on the stigma? Plant Ecology 216: 1407-1417. doi:10.1007/s11258-0150519-z.

El Ghazali GE, Satti AM, Tsuji SI. 1997. Intra-specific pollen polymorphism in Mimosa pigra (Mimosaceae). Grana 36: 279-283. doi:10.1080/00173139709362617.

Fernández M, Rodríguez-García M. 1989. Developmental changes in the aperture during pollen grain ontogeny in Olea europaea L. New Phytologist 111: 717-723. doi:10.1111/ j.1469-8137.1989.tb02367.x.

Ganino T, Bartolini G, Fabbri A. 2006. The classification of olive germplasm. The Journal of Horticultural Science and Biotechnology 81: 319-334. doi:10.1080/14620316.2006. 11512069 .

Halbritter H, Ulrich S, Grímsson F, Weber M, Zetter R, Hesse M, Buchner R, Svojtka M, Frosch-Radivo A. 2018. Illustrated pollen terminology. Cham: Springer.

Hannachi H, Marzouk S. 2012. Flowering in the wild olive (Olea europaea L.) tree (oleaster): Phenology, flower abnormalities and fruit set traits for breeding the olive. African Journal of Biotechnology 11: 8142-8148.

Harfouche A, Nedjahi A, Ellatifi M, Daly-Hassen H. 2005. Les ressources génétiques forestières nord-africaines et leur conservation. Revue Forestière Française 57: 15-32.

Hesse M, Halbritter H, Zetter R, Weber M, Buchner R, FroschRadivo A, Ulrich S. 2009. Pollen terminology: An illustrated handbook. Vienna: Springer.

Javadi T, Arzani K. 2001. Pollen morphology of five Iranian olive (Olea europaea L.) cultivars. Journal of Agricultural Science and Technology 3: 37-42.

John H, Birks B. 1978. Geographic variation of Picea abies (L.) Karsten pollen in Europe. Grana 17: 149-160. doi:10.1080/ 00173137809431960.

Kaniewski D, Van Campo E, Boiy T, Terral JF, Khadari B, Besnard G. 2012. Primary domestication and early uses of the emblematic olive tree: Palaeobotanical, historical and molecular evidence from the Middle East. Biological Reviews 87: 885-899.

Klepo T, De la Rosa R, Satovic Z, León L, Belaj A. 2013. Utility of wild germplasm in olive breeding. Scientia Horticulturae 152: 92-101. doi:10.1016/j.scienta.2012.12.010.

Klepo T, Toumi A, De La Rosa R, León L, Belaj A. 2014. Agronomic evaluation of seedlings from crosses between the main Spanish olive cultivar 'Picual'and two wild olive trees. The Journal of Horticultural Science and Biotechnology 89: 508-512. doi:10.1080/14620316.2014.11513113.

Koubouris G, Metzidakis I, Vasilakakis M. 2012. Intraspecific variation in pollen viability, germination and ultrastructure of Olea europaea L. African Journal of Biotechnology 11: 1344213446.

Kurtz EB Jr., Liverman JL. 1958. Some effects of temperature on pollen characters. Bulletin of the Torrey Botanical Club 85: 136-138.

Laaribi I, Mezghani Aiachi M, Gouta H, Giordano C, Salvatici M, Labidi F, Mars M. 2018. Pollen ultrastructural image analysis among ancient native olive genotypes in the central eastern Tunisia. Journal of Agricultural Science and Technology 19(2): 401-413.

Langgut D, Cheddadi R, Carrión JS, Cavanagh M, Colombaroli D, Eastwood WJ, Greenberg R, Litt T, Mercuri AM, Miebach A. 2019. The origin and spread of olive cultivation in the Mediterranean Basin: The fossil pollen evidence. The Holocene 29: 902-922. doi:10.1177/ 0959683619826654.

Lanza B, Marsilio V, Martinelli N. 1996. Olive pollen ultrastructure: Characterization of exine pattern through image analysis-scanning electron microscopy (IA-SEM). Scientia Horticulturae 65: 283-294. doi:10.1016/0304-4238(95) 00868-3.

Liphschitz N, Gophna R, Hartman M, Biger G. 1991. The beginning of olive (Olea europaea) cultivation in the Old World: A reassessment. Journal of Archaeological Science 18: 441-453. doi:10.1016/0305-4403(91)90037-P.

Lobreau-Callen D. 1975. Les variations dimensionnelles du pollen du genre Ilex (Aquifoliaceae) et leurs rapports avec le climat. Bulletin de La Société Botanique de France 122: 179-199. doi:10.1080/00378941.1975.10835654.

Messora R, Florenzano A, Torri P, Mercuri AM, Muzzalupo I, Arru L. 2017. Morphology and discrimination features of pollen from Italian olive cultivars (Olea europaea L.). Grana 56: 204-214. doi:10.1080/00173134.2016. 1216594.

Najmaddin C. 2016. anatomical and palynological studies of Olea europaea L. Bangladesh Journal of Botany 45: 321-326. 
Pacini E, Juniper B. 1979a. The ultrastructure of pollen-grain development in the olive (olea europaea). 1. Proteins in the pore. New Phytologist 83: 157-163.

Pacini E, Juniper B. 1979b. The ultrastructure of pollen-grain development in the olive (olea europaea). 2. Secretion by the tapetal cells. New Phytologist 83: 165-174.

Porch T, Jahn M. 2001. Effects of high-temperature stress on microsporogenesis in heat-sensitive and heat-tolerant genotypes of Phaseolus vulgaris. Plant, Cell \& Environment 24: 723-731. doi:10.1046/j.1365-3040.2001.00716.x.

Punt W, Hoen P, Blackmore S, Nilsson S, Le Thomas A. 2007. Glossary of pollen and spore terminology. Review of Palaeobotany and Palynology 143: 1-81. doi:10.1016/j. revpalbo.2006.06.008.
Ribeiro H, Cunha M, Calado L, Abreu I. 2008. Pollen morphology and quality of twenty olive (Olea europaea L.) cultivars grown in Portugal. Acta Horticulturae 949: 259-264.

Rivas-Martínez, S. 2005. Avances en Geobotánica. Madrid: Publicaciones Academia Nacional de Farmacia.

Roselli, G. 1979. Identification of olive cultivars from some pollen characters. Rivista di Ortoflorofrutticoltura. 63: 435-445.

Silva L, Zambon CR, Pio R, Oliveira A, Gonçalves ED. 2016. Establishment of growth medium and quantification of pollen grains of olive cultivars in Brazil's subtropical areas. Bragantia 75: 26-32.

Zohary D, Hopf M. 2000. Domestication of plants in the Old World: The origin and spread of cultivated plants in West Asia, Europe and the Nile Valley. Oxford: Oxford University Press. 